\title{
PENGARUH TEKNIK AKUPRESSURE TERHADAP NYERI PUNGGUNG PADA IBU HAMIL DI WILAYAH PUSKESMAS JOGONALAN I KLATEN
}

\author{
Niken Tri Sukeksi, Gita Kostania, Emy Suryani \\ Kementerian Kesehatan Politeknik Kesehatan Surakarta Jurusan Kebidanan
}

\begin{abstract}
Acupressure, Back Pain, Pregnancy. Acupressure is effective to relieve back pain in Meridian point. Acupressure technique is done to help pregnant women in relieving complaints in pregnancy such as nausea and vomiting. In labour process, this technique can be an induction of labor, and can reduce anxiety. The purpose is to know the influence of acupressure technique to relieve back pain for pregnant women in Puskesmas Jogonalan I area of Klaten. Research is pre experimental design with one group pretest posttest approach. The population is all pregnant women in Puskesmas Jogonalan I area of Klaten. The population target is all third trimester of pregnant women in Puskesmas Jogonalan I area of Klaten. Technique sampling is purposive sampling with 30 peopole, ang using t-test data analysis. The characteristics of respondents showed that most of them are 20-35 years old, their gestational age are 3137 weeks, their occupation are housewives, and most of them have 2-3 children. Degree of back pain in pregnant women before acupressure as many as 21 people (70\%) are in severe pain. Degree of back pain in pregnant women after given acupressure as many as 24 people (80\%) are in mild pain. There is influence of acupressure technique to relieve back pain for pregnant women in Puskesmas Jogonalan I area of Klaten $(t=$ 9,893; $p=0,001<0,05)$.
\end{abstract}

Keywords: Acupressure, Back Pain, Pregnancy.

Abstrak: Akupressure, Nyeri Punggung, Ibu Hamil. Akupresur efektif dalam mengatasi nyeri punggung di titik meridian. Teknik akupresur dilakukan untuk membantu mengurangi keluhan ibu hamil seperti mual muntah, pada ibu bersalin seperti induksi persalinan, mengurangi kecemasan, dan keluhan nyeri punggung selama proses persalinan. Tujuan penelitian untuk mengetahui Pengaruh Akupresure terhadap Nyeri Punggung Ibu Hamil di Wilayah Kerja Puskesmas Jogonalan I Klaten. Metode penelitian Pre Experiment dengan pendekatan one group pretest posttest design. Populasi aktual pada penelitian ini adalah semua ibu hamil di wilayah Puskesmas Jogonalan I Klaten. Populasi target adalah semua ibu hamil trimester III di wilayah Puskesmas Jogonalan I Klaten. Teknik sampling purposive sampling sebanyak 30 ibu hamil, analisis hipotesis menggunakan Uji t-test. Hasil penelitian: karakteristik umur responden sebagian besar 20-35 tahun, umur kehamilan sebagian besar adalah 31-37 minggu, pekerjaan sebagian besar adalah ibu rumah tangga dan jumlah anak sebagian besar adalah 2-3 anak. Nyeri punggung pada ibu hamil sebelum diberikan akupressure di wilayah kerja Puskesmas Jogonalan I Klaten sebanyak 21 orang (70\%) adalah nyeri berat. Nyeri punggung pada ibu hamil sesudah diberikan akupressure di wilayah Puskesmas Jogonalan I Klaten sebanyak 24 orang $(80 \%)$ adalah nyeri ringan. Uji hipotesis dengan nilai $\mathrm{t}=9,893$ dan $(\mathrm{p} 0,001<0,05)$. Kesimpulan: ada pengaruh 
akupresure terhadap nyeri punggung ibu hamil di wilayah kerja Puskesmas Jogonalan I Klaten.

Kata Kunci : Akupressure, Nyeri Punggung, Ibu Hamil

\section{PENDAHULUAN}

Kehamilan merupakan suatu proses yang alami dan normal. Selama hamil seorang ibu mengalami perubahanperubahan yang terjadi baik fisik maupun psikologis. Perubahan-perubahan tersebut menyebabkan ibu hamil mengalami ketidaknyamanan (Manuaba, 2011).

Rasa tidak nyaman yang dirasakan oleh ibu hamil biasanya berbeda-beda pada setiap trimester kehamilan. Perubahan yang terjadi selama kehamilan sering kali menjadi keluhan bagi ibu hamil diantaranya adalah mual muntah pada awal kehamilan, konstipasi, varises vena (pembuluh balik), gangguan berkemih, hemoroid, dan pembengkakan pada tungkai dan kaki serta nyeri punggung (Bobak, 2010).

Nyeri punggung merupakan nyeri yang terjadi pada area lumbosakral. Nyeri punggung biasanya akan meningkat intensitasnya seiring dengan pertambahan usia kehamilan karena nyeri ini merupakan akibat pergeseran pusat gravitasi dan perubahan postur tubuhnya (Varney, 2008).

Wanita hamil yang mengalami nyeri punggung sekitar $88,2 \%$. Wanita hamil usia kehamilan 14-22 minggu mengalami kejadian nyeri punggung bawah sekitar $62 \%$. Nyeri pada punggung selama kehamilan bervariasi antara 35-60 \%. Hasil penelitian Ariyanti (2012) didapatkan bahwa $68 \%$ ibu hamil mengalami nyeri punggung dengan intensitas sedang, dan 32\% ibu hamil mengalami nyeri punggung dengan intensitas ringan. Diantara semua wanita ini, 47-60 \% melaporkan bahwa nyeri punggung terjadi pada kehamilan 5-7 bulan (Renata, 2009).

Perubahan ini disebabkan oleh berat uterus yang membesar, membungkuk yang berlebihan, berjalan tanpa istirahat, dan angkat beban. Gejala nyeri punggung ini juga disebabkan oleh hormon estrogen dan progesteron yang mengendurkan sendi, ikatan tulang dan otot dipinggul (Tiran, 2008).

Berbagai macam teknik komplementer yang dapat diterapkan pada untuk pengobatan nyeri punggung bawah pada kehamilan yang telah dikembangkan antara lain pijat $(61,4 \%)$, relaksasi (42,6\%), khiropraktik (36,6\%), akupunktur $(44,6 \%)$, yoga $(40,6 \%)$ dan akupresur. Akupresur adalah salah satu bentuk fisioterapi dengan memberikan pemijatan dan stimulasi pada titik-titik tertentu pada tubuh yang berguna untuk mengurangi bermacam-macam sakit dan nyeri serta mengurangi ketegangan, kelelahan dan berbagai penyakit dengan maksud mengaktifkan kembali peredaran energi vital.

Pengobatan nyeri punggung bawah dengan akupresur, dengan hasil bahwa akupresur efektif dalam mengatasi nyeri punggung dan manfaatnya bertahan selama enam bulan. Selama ini teknik akupresur dilakukan untuk membantu mengurangi keluhan ibu hamil seperti mual muntah, pada ibu bersalin seperti induksi persalinan, mengurangi kecemasan, dan keluhan nyeri punggung selama proses persalinan. Ibu hamil belum pernah dilakukan teknik akupresur untuk 
mengurangi keluhan nyeri punggung bawah. Selama ini ibu hamil menganggap bahwa keluhan nyeri punggung merupakan hal yang wajar terjadi selama kehamilan, sehingga upaya yang selama ini dilakukan untuk mengurangi keluhan nyeri punggung bawah hanya melakukan istirahat.

Berdasarkan studi pendahuluan yang dilakukan kepada 10 ibu hamil trimester III di wilayah Puskesmas Jogonalan I Klaten, dengan melakukan wawancara tentang keluhan nyeri punggung pada saat kehamilan didapatkan bahwa 6 ibu hamil mengatakan mengalami keluhan nyeri punggung bagian bawah sejak usia kehamilan masuk 8 bulan dan untuk mengurangi keluhannya dengan istirahat (berbaring). Empat ibu hamil lainnya ketika ditanya tentang keluhan nyeri punggung mengatakan pernah nyeri dan menanganinya dengan akupresure.

Melihat uraian fakta dan fenomena tersebut peneliti menjadi sangat tertarik untuk melakukan penelitian mengenai "Pengaruh Akupresure terhadap Nyeri Punggung Ibu Hamil di Wilayah Kerja Puskesmas Jogonalan I Klaten”.

Tujuan umum untuk mengetahui Pengaruh Akupresure terhadap Nyeri Punggung Ibu Hamil di Wilayah Kerja Puskesmas Jogonalan I Klaten.

\section{METODE PENELITIAN}

Rancangan penelitian yang digunakan dalam penelitian ini adalah pre Experiment dengan pendekatan one group pretest posttest design. Tempat penelitian akan dilakukan di Wilayah Puskesmas Jogonalan I Klaten pada bulan Maret sampai dengan Juli 2017. Populasi aktual pada penelitian ini adalah semua ibu hamil di wilayah Puskesmas Jogonalan I Klaten. Populasi target adalah semua ibu hamil trimester III di wilayah Puskesmas Jogonalan I Klaten. Teknik sampling dalam penelitian ini adalah purposive sampling. uji statistic yang digunakan adalah uji beda (T-Test) berpasangan.

\section{HASIL PENELITIAN}

Hasil penelitian tentang pengaruh teknik akupressure terhadap nyeri punggung pada ibu hamil adalah sebagai berikut :

1. Karakteristik Responden

Karakteristik responden dalam penelitian ini meliputi umur, umur kehamilan, pekerjaan dan jumlah anak.

Tabel 1

Distribusi Frekuensi Karakteristik Responden Berdasarkan Umur, Umur Kehamilan, Pekerjaan dan Jumlah Anak di Puskesmas Jogonalan Klaten

\begin{tabular}{llcr}
\hline No & Karakteristik & $\mathrm{f}$ & $\%$ \\
\hline 1 & Umur & & \\
& $<20$ tahun & 2 & 6,7 \\
& 20-35 tahun & 26 & 86,7 \\
& $>35$ tahun & 2 & 6,6 \\
2 & Umur Kehamilan & & \\
& 28 -30 minggu & 6 & 20 \\
& 31-37 minggu & 24 & 80 \\
3 & Pekerjaan & & \\
& IRT & 25 & 83,3 \\
& PNS & 0 & 0 \\
& Swasta & 5 & 16,7 \\
4 & Jumlah Anak & & \\
& 1 anak & 8 & 26,7 \\
& 2-3 anak & 22 & 73,3 \\
& $>3$ anak & 0 & 0 \\
\hline & Jumlah & 30 & 100,0 \\
\hline
\end{tabular}

Berdasarkan tabel 1, karakteristik responden berdasarkan umur sebagian besar responden umur 20-35 tahun sebanyak 26 orang (86,7\%). Umur kehamilan responden sebagian besar adalah 31-37 minggu sebanyak 24 orang (80\%). Pekerjaan responden sebagian besar adalah ibu rumah tangga sebanyak 25 orang $(83,3 \%)$. Jumlah anak responden 
sebagian besar adalah 2-3 anak sebanyak 22 orang $(73,3 \%)$.

2. Nyeri punggung pada ibu hamil sebelum diberikan akupressure di wilayah kerja Puskesmas Jogonalan I Klaten

Tabel 2

Distribusi Frekuensi Nyeri Punggung

Ibu Hamil sebelum diberikan

akupressure di wilayah kerja

Puskesmas Jogonalan I Klaten

\begin{tabular}{cccr}
\hline No & Nyeri Punggung & f & \multicolumn{1}{c}{$\%$} \\
\hline 1 & Tidak ada nyeri & 0 & 0,0 \\
2 & Nyeri Ringan & 0 & 0,0 \\
3 & Nyeri Sedang & 9 & 30,0 \\
4 & Nyeri Berat & 21 & 70,0 \\
5 & Nyeri Berat Sekali & 0 & 0,0 \\
\hline & Jumlah & 30 & 100,0
\end{tabular}

Berdasarkan tabel 2, frekuensi

didapatkan nyeri punggung pada ibu hamil sebelum diberikan akupressure sebagian besar adalah nyeri berat sebanyak 21 orang $(70 \%)$.

3. Nyeri punggung pada ibu hamil sesudah diberikan akupressure di wilayah Puskesmas Jogonalan I Klaten.

\section{Tabel 3}

Distribusi Frekuensi Nyeri Punggung

Ibu Hamil setelah diberikan

akupressure di wilayah kerja

Puskesmas Jogonalan I Klaten

\begin{tabular}{|c|c|c|c|}
\hline No & Nyeri Punggung & $\mathrm{f}$ & $\%$ \\
\hline 1 & Tidak ada nyeri & 4 & 13,3 \\
\hline 2 & Nyeri Ringan & 24 & 80,0 \\
\hline 3 & Nyeri Sedang & 2 & 6,7 \\
\hline 4 & Nyeri Berat & 0 & 0,0 \\
\hline 5 & Nyeri Berat Sekali & 0 & 0,0 \\
\hline & Jumlah & 30 & 100,0 \\
\hline
\end{tabular}

didapatkan nyeri punggung pada ibu hamil setelah diberikan akupressure sebagian besar adalah nyeri ringan sebanyak 24 orang $(80 \%)$.

4. Pengaruh Akupresure terhadap Nyeri Punggung Ibu Hamil di Wilayah Kerja Puskesmas Jogonalan I Klaten.

Tabel 4

Pengaruh Akupresure terhadap Nyeri Punggung Ibu Hamil di Wilayah Kerja Puskesmas Jogonalan I Klaten

\begin{tabular}{|c|c|c|c|c|c|c|c|}
\hline & \multirow[b]{2}{*}{$\mathrm{N}$} & \multirow[b]{2}{*}{$\begin{array}{c}\text { Mea } \\
\text { n }\end{array}$} & \multirow[b]{2}{*}{ SD } & \multicolumn{2}{|c|}{ CI } & & \multirow[b]{2}{*}{$\mathrm{p}$} \\
\hline & & & & $\begin{array}{c}\text { Upp } \\
\text { er }\end{array}$ & $\begin{array}{c}\text { Low } \\
\text { er }\end{array}$ & & \\
\hline Pre & $\begin{array}{l}3 \\
0\end{array}$ & 5,9 & $\begin{array}{c}1,0 \\
4\end{array}$ & 1,90 & 2,80 & $\begin{array}{c}9,89 \\
3\end{array}$ & 0,00 \\
\hline $\begin{array}{l}\text { Po } \\
\text { st }\end{array}$ & $\begin{array}{l}3 \\
0\end{array}$ & 2,6 & $\begin{array}{c}1,2 \\
9\end{array}$ & & & & \\
\hline
\end{tabular}
statistik menunjukkan nilai mean sebelum dilakukan akupresure yaitu 5,9 dan setelah dilakukan akupresure dengan nilai mean 2,6 , nilai $\mathrm{t}=9,893$ dan $\mathrm{p}=0,001$ $(\alpha<0,05)$. Hal ini menunjukkan $\mathrm{Ha}$ diterima dan Ho ditolak jadi ada pengaruh Akupresure terhadap Nyeri Punggung Ibu Hamil di Wilayah Kerja Puskesmas Jogonalan I Klaten.

\section{PEMBAHASAN}

Hasil uji statistik menunjukkan nilai mean sebelum dilakukan akupresure yaitu 5,9 dan setelah dilakukan akupresure dengan nilai mean 2,6 , nilai $\mathrm{t}=9,893$ dan $p=0,001(\alpha<0,05)$. Hal ini menunjukkan Ha diterima dan Ho ditolak jadi ada pengaruh Akupresure terhadap Nyeri Punggung Ibu Hamil di Wilayah Kerja Puskesmas Jogonalan I Klaten.

Akupressure adalah bentuk fisioterapi dengan memberikan pemijatan dan stimulasi pada titik titik tertentu pada tubuh (garis aliran energi atau meridian) untuk menurunkan nyeri atau mengubah fungsi organ (Widyaningrum, 2013). 
Ketika titik titk akupresure distimulasi tubuh akan melepaskan ketegangan otot, meningkatkan sirkulasi darah dan meningkatkan kekuatan hidup energi tubuh (qi) untuk membantu penyembuhan (Wong, 2011). Menurut Astuti (2010) Nyeri punggung yang terjadi selama kehamilan dapat diakibatkan oleh :

1) Pembesaran rahim akibat janin yang semakin besar yang menekan tulang belakang dan panggul, serta mengubah postur tubuh ibu menjadi ke depan (lordosis).

2) Kejang otot karena tekanan terhadap saraf di tulang belakang.

3) Penambahan ukuran payudara.

4) Kadar hormon yang meningkat menyebabkan ligament dan sendi menjadi lemah.

5) Keletihan

6) Mekanisme tubuh yang kurang baik saat mengangkat barang dan mengambil barang.

Saat kehamilan ketika membusungkan tubuh, rahim akan terdorong ke depan, dan karena rahim hanya ditahan ligamen dari belakang dan bawah (kanan), maka ligamen tersebut akan tegang dan menyebabkan rasa nyeri di pangkal paha serta sebagian kecil punggung (Neil, 2007). Hormon progesteron dan hormon relaksasi menyebabkan relaksasi jaringan ikat dan otot-otot. Hal ini terjadi maksimal pada satu minggu terakhir kehamilan. Proses relaksasi ini memberikan kesempatan pada panggul untuk meningkatkan kapasitasnya sebagai persiapan persalinan, tulang pubis melunak menyerupai tulang sendi, sambungan sendi sacrococcigus mengendur membuat tulang koksigis bergeser ke arah belakang sendi panggul yang tidak stabil. Pada ibu hamil, hal ini dapat menyebabkan sakit pinggang.
Postur tubuh wanita secara bertahap mengalami perubahan karena janin membesar dalam abdomen sehingga untuk mengompensasi penambahan berat badan ini, bahu lebih tertarik ke belakang dan tulang lebih melengkung, sendi tulang belakang lebih lentur dan dapat menyebabkan nyeri punggung pada beberapa wanita (Vivian dan Sunarsih, 2011). Gejala-gejala nyeri punggung menurut West (2010) rasa sakit sepanjang punggung atau panggul, lemah atau sakit pada bagian bokong dan kaki, sulit berjalan karena sakit pada kaki.

Rasa nyeri dan pegal pegal di bagian punggung sebenarnya disebabkan kerena pergeseran titik keseimbangna tubuh akibat beban berat pada perut. Pada saat hamil, setengah dari berat tubuh terletak didepan. Untuk menjaga keseimbangan, tanpa sadar biasanya bahu akan condong kebelakang. Posisi tubuh yang salah dan dipaksakan secara menetap inilah yang menyebabkan ketegangan otot pada bagian punggung. Spasme pada otot punggung ini akan terus berlangsung selama kehamilan jika tidak ditangani, karena postur yang menyebabkan spasme ini mengakibatkan nyeri pada punggung bahkan menjalar sampai ke pinggul.

Perubahan patologi ditandai dengan adanya nyeri yang bertambah saat melakukan gerakan (nyeri gerak), dan juga adanya nyeri saat dilakukan penekanan (nyeri tekan), kesalahan sikap misalnya cara duduk, cara berdiri, dan berjalan, nyeri berkurang saat digunakan untuk berbaring (Kartika, 2012).

Penelitian Sudarmanto (2008) bahwa ada Perbedaan Efek Analgesia Akupunktur antara Metoda Segmental dan Non Segmental Pada Nyeri Punggung Bawah. Hasil penelitian Ariyanti (2012) didapatkan bahwa $68 \%$ ibu hamil 
mengalami nyeri punggung dengan intensitas sedang, dan $32 \%$ ibu hamil mengalami nyeri punggung dengan intensitas ringan. Terapi akupresur dapat digunakan untuk menghilangkan rasa sakit, menguatkan sistem reproduksi seksual, detoksifikasi tubuh untuk kesehatan yang lebih baik. Menjaga kecantikan, membuat awet muda, dan meringankan nyeri otot punggung.

Penelitian menunjukkan terjadi perubahan atau penurunan nyeri punggung setelah diberikan teknik akupresure. Hal ini ditunjukkan dari nilai mean 5,6 sebelum dilakukan akupressure menjadi 2,6 setelah dilakukan akupressure. Teknik akupressure dilakukan pemijatan pada titik akupressure menggunakan ibu jari selama 30 kali putaran ,arah putaran searah dengan jarum jam ,tekanan pijatan tak boleh kuat dan intervensi dilakukan oleh seorang fisioterapis

Berdasarkan tabel 4.1 karakteristik responden berdasarkan umur sebagian besar responden umur 20-35 tahun sebanyak 26 orang $(86,7 \%)$.yang mana nyeri mulai dirasakan pada mereka yang berumur dekade kedua dan insiden tertinggi dijumpai pada dekade kelima.Pada umumnya nyeri punggung bawah menyerang remaja mempunyai sosial kehidupan yang tinggi $(20-24$ tahun) dan mencapai puncaknya pada mereka yang berusia lebih dari 40 tahun (Secer at al ,2010). Umur kehamilan responden yang mengalami nyeri punggung sebagian besar pada kehamilan 31-37 minggu sebanyak 24 orang (80\%). Nyeri punggung merupakan nyeri yang terjadi pada area lumbosakaral, nyeri biasanya akan meningkat intensitasnya seiring dengan pertambahan usia kehamilan karena nyeri merupakan akibat pergeseran pusat gravitasi dan perubahan postur tubuh (Varney, 2008). Pada penelitian ini responden yang mengalami nyeri punggung sebagian besar adalah ibu rumah tangga sebanyak 25 orang $(83,3 \%)$. Responden yang mengalami nyeri punggung sebagian besar ibu yang sedang hamil ke 2-3 adalah sebanyak 22 orang $(73,3 \%)$.

Kesimpulan

1. Karakteristik responden umur sebagian besar 20-35 tahun, umur kehamilan sebagian besar adalah 31-37 minggu, pekerjaan sebagian besar adalah ibu rumah tangga dan jumlah anak sebagian besar adalah 2-3 anak.

2. Nyeri punggung pada ibu hamil sebelum diberikan akupressure di wilayah kerja Puskesmas Jogonalan I Klaten sebanyak 21 orang $(70 \%)$ adalah nyeri berat.

3. Nyeri punggung pada ibu hamil sesudah diberikan akupressure di wilayah Puskesmas Jogonalan I Klaten sebanyak 24 orang $(80 \%)$ adalah nyeri ringan.

4. Ada Pengaruh Akupresure terhadap Nyeri Punggung Ibu Hamil di Wilayah Kerja Puskesmas Jogonalan I Klaten dengan nilai $p=0,001(\alpha<0,05)$.

\section{KESIMPULAN DAN SARAN}

Akupresure dapat mengurangi nyeri punggung pada ibu hamil.

Saran yang diberikan sesuai dengan hasil penelitian ini adalah:

1. Bagi Ibu Hamil

Ibu hamil yang mengalami rasa tidak nyaman dapat mengetahui dan mampu melaksanakan upaya meningkatkan kenyamanan dengan cara akupressure.

2. Bagi Bidan

Penelitian ini dapat digunakan bidan untuk dasar pertimbangan melakukan 
intervensi mandiri melalui pemberian akupressure pada ibu hamil yang mengalami rasa tidak nyaman dengan cara memberikan usapan pada punggung ibu hamil.

3. Bagi Puskesmas

Dapat digunakan sebagai masukan bagi tempat pelayanan atau institusi setempat guna meningkatkan pelayanan dan pengembangan ilmu keperawatan, khususnya untuk penatalaksanaan non-farmakologis bagi ibu hamil yang mengalami rasa tidak nyaman.

4. Bagi Peneliti

Hasil penelitian ini dapat digunakan sebagai bahan referensi untuk melakukan penelitian selanjutnya dengan menggunakan metode yang berbeda atau variabel yang berbeda.

\section{DAFTAR RUJUKAN}

Gan L.G, Azrul A dan Sugito W (2004). A Primer on Family Medicine Practice. Singapore: Singapore International Foundation

Lwanga.S.K dan Lameshow S (1991). Sample Size Determination in Health Studies. Geneva : World Health Organization.

Teasell RW dan Finestone HM (1999). Sosioeconomic factors and work Yin G, Liu Z (2000). Advanced Modern Chinese Acupuncture Therapy. Beijing : New World Press. disability: clues to managing chronic pain disorder. Pain research \& Management 4 : 89-92

Thai Tu N (1998). Semiology Therapy and Analgesia in Acupunture. Hanoi : Gioi Publishers.

Tjatchristanto H (2005). Elektrostimulator pada Akupunktur. Meridian $12 \mathrm{No}$ $3: 147-154$

Turner C, Bahra A dan Cikurel K (2006). Neurology second edition. Edinburgh : Mosby.

Ulett GA (1982). Principles and Practice of Physiologic Acupuncture, St. Louis, Missouri; Warren $\mathrm{H}$. Green,Inc.

Wahyudi JR (2007). Gambaran Karakteristik dan Pemanfaatan Terapi Akupunktur pada Penderita Sindrom Bi Punggung Bawah ( Nyeri Punggung Bawah ) di Klinik Akupunktur LP3A Tahun 2004 2005. Meridian 14 No1: 43-52

Webb C.W dan O`Connor F.G (2004). "Low Back Pain", di dalam SouthPaul J.E, Lewis E.L, Matheny S.C, Current Diagnosis and Treatment in Family Medicine. New York.: Lange Medical Books/McGrawHill. 